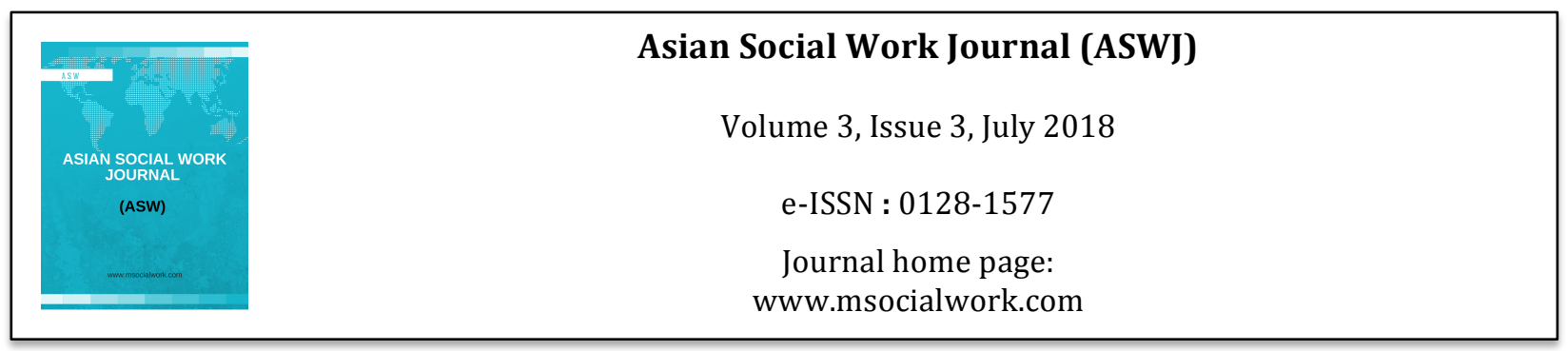

\title{
Why Students Choose Social Work?
}

\author{
Akbar Prayuda ${ }^{1}$, Fadhil Nurdin ${ }^{2}$ \\ ${ }^{1}$ Yayasan Kesejahteraan Sosial Asiana \\ 2Universiti Sains Malaysia (USM)
}

Corrrespondence: Akbar Prayuda (akbar_prayuda@gmail.com)

\begin{abstract}
University and college that organize the education of social workers and social welfare, give a chance for Indonesia to produce professional practitioners in social worker sector to be much better. The students of social work education hoped having ability about professional helping process, so that can help an individual, family, group and society to solve the social problem. This picture define that social work has a great future for develop our nation, so important to produce a prosperity social worker. The problem is, profession of social worker had not recognized by society, many people did not know what social work is. Grounded on this fact, it interest to find out why candidate student make a choice to study in social work or social welfare, whereas they don't know about social worker profession. This research purposed to knowing why student of social work have been made a future decision to continue study in Social Work Scholar. This qualitative research use case study approach was success collecting information from six informants in four different universities in Bandung and Makassar by pursposivesnowball. Six informant clarified that they have continue study to social work by some reason, (1) obey their parents and family, (2) They need to work for government (ASN) after graduated, (3) in a pinch because of particular situation. Recommendation of this study emphasizes on give attention to social work and social welfare education system, optimize social work existence in public and encourage government to legitimating social work act in Indonesia.
\end{abstract}

Key words: social work, social welfare, social work profession, education

\section{Introduction}

Social welfare requires a variety of resources to achieve its objectives, it is necessary for social workers as a profession that provides services to improve economic prosperity and social welfare. The social worker is a profession that provides the opportunity to work in many different settings with a variety of problems, issues, different needs (Dubois, 1999: 6). The main goal of social workers is to improve the quality of individuals life, families, groups and communities, in order to perform its functions and its role in society. Social workers provide services based on the knowledge, skills and values obtained from the education and training of professional social workers, so that social workers not only as a volunteer or provide assistance alone but jobs that provide professional help. Helping Process in the form of services provided to solve a diverse social problems and vary based on the type of problems, approaches, theories, and models used. In the process of social workers know about the theories, models, or approaches used comes from the knowledge that was supported by the skill, and wrapped with ethical and values of social workers. This makes the profession of social workers like doctors, teachers, nurses, psychologists that knowledge gained from education or lectures at universities. 
In Indonesia currently there are 37 colleges/universities that organizes courses Social Work / Social Welfare, both government and private owned tied in Social Work Education Association expressed by (http://www.kemsos.go.id 2013); By the college education of social workers and social welfare is expected can produce the social worker with the capabilities who able to contribute in the provision of social services to help people, both individuals, groups, families, and communities. From the college education of social workers and social welfare would hope the birth of professional practitioners who pursue the social workers is much better. Students who take social work education has the ability to process a professional help. Because they are equipped with the knowledge of all of the good social workers understanding of the theory, values, principles, ethics, methods and various things that support social work knowledge, and then students also provided a practical skills acquired in the field of direct practice. Curriculum that provides the right portion to be a social worker by bring knowledge into students on all matters concerning social worker or social welfare, then the student will understand about the profession of social work.

Progress in developing the social welfare and social work in Indonesia is very necessary. Advancement of information and technology, the begining of the Asean Economic Community in 2015, the political and economic dynamics in Indonesia that might have an impact on the increase in social problems when it has no prevented by makes a grass root level people or minorities become prosperous. Although, known as a profession that can be equated with the help profession like teachers and doctors, but the development of social workers should be encouraged, because the social problems will never be completed, especially in countries with a large territory and big population like Indonesia. The fact, nowadays profession of social worker unrecognized in public, existence of social work can not compared with existence of doctor or teacher, but still, any people apply to study in social work or social welfare. So, to find out the phenomenon about the reason of the student come to learn about social work or social welfare, this study held to try to reveal why students can be made a decision to choose to study in social work or social welfare and how they recognize a profession of social worker before they decided to study in social welfare or social work major.

\section{Literature Review}

\section{Social Welfare}

At the time of Indonesia's independence in 1945, officials of this country when formulates the base ideology of Pancasila our country and to develop the Law of the Republic of Indonesia 1945, which is until today use by the country's leaders to organize the state and make society to get well being in Indonesia. Development of social welfare is the embodiment of the nation's efforts to achieve the goals mandated by the Constitution of the Republic of Indonesia 1945. Fifth Pancasila state that, social justice for all Indonesian people, and the Preamble to the Constitution of the Republic of Indonesia of 1945 mandates the state to protect all the people of Indonesia and the country of Indonesia, promote the general welfare, the intellectual life of the nation, and participate in the establishment of a world order based on freedom, lasting peace and social justice, then hoped a social welfare achieved.

The definition of social welfare according to Friedlander is as follows:

Social welfare is the organized system of social services and institutions, designed to aid individuals and groups to attain satisfying standards of life and health, and personal and social relationships that permit them to develop Reviews their full capacities and promote Reviews their well being in harmony with the needs of Reviews their families and the community (Friedlander on Adi, 2000)

According to Friedlander, social welfare is an organized system in which there are a social service and various other institutions that designed to help individuals and groups to achieve prosperity both in the scope of adequate health and in social relations and welfare in order to develop capabilities fully in accordance by the needs of families and communities. The definition suggests that social welfare is a 
design system that organizes institutions and social services to help people, groups, families or individuals achieve prosperity in the health part and social relations.

Meanwhile, according to Suharto (2009) notion of social welfare as follows:

Kesejahteraan sosial adalah suatu institusi atau bidang kegiatan yang melibatkan aktivitas terorganisir yang diselenggarakan baik oleh lembaga-lembaga pemerintah maupun swasta yang bertujuan untuk mencegah, mengatasi atau memberikan kontribusi terhadap pemecahan masalah sosial dan peningkatan kualitas hidup individu, kelompok dan masyarakat. (p. 16)

Suharto said that, Social welfare is an institution or some activities involving organized activities by both government agencies and private sector aimed to prevent, resolve or contribute to solving social problems and improving the quality of life of individuals, groups and communities. Explanation above implies that social welfare problems can not be addressed by unilaterally and without a clearly organized social conditions experienced by the community. Social dynamics changes led to social problems handling, it must be planned carefully and continuously. Because of the social problems will always be there and appeared during the reign still running and continue the human life.

The educational program, now run by several universities in Indonesia with social welfare courses absorbing interest of students for social welfare can be seen as a science or academic discipline that studies social policy, social work, and social services programs. Such as sociology, psychology, anthropology, economics, politics, development studies, and social work, social welfare science seeks to develop science to identify social problems, causes and strategies to overcome them. In the early days of its development, social welfare has developed knowledge base on the other social science disciplines, especially philosophy, sociology, psychology, anthropology, politics and economics. In recent years, the social welfare major has been very active in conducting various research projects and increasingly specific scientific development (Suharto, 2009).

\section{Social Work}

Social work profession known as a human helper, which is not an easy job, with connotations of social work is diverse and dynamic. So that social work has a definition relatively, by place, time, situation or perspective or its review and subject to change in accordance with the development of society (Heru Dwi Sukoco, 1991). But by some experts have had their own perspective on the definition of social work.

Social work as a profession can not be equated with social work as a layman. According to common sense all good deeds for others already said social work. For example, a person who gives money to beggars, street children and others, to contribute to the unfortunate neighbors or to the victims of natural disasters, helping the sick, and other activities was already considered social work (Adi Fahrudin, 2012).

As for the view of some experts on social work including Max Siporin in Adi fahrudin states that "Social work is defined as a social institutional method of helping people to Prevent and to resolve Reviews their social problems, to restore and enhance their social functioning". According to Max Siporin social work is a method of social institutions, where the agency aims to help people in preventing and solving social problems, to restore and improve their social functioning. Furthermore Siporin states that social work is a social institution, a human service profession, and an art technical and scientific practices.

Then Charles Zastrow on his book Introduction to Social Welfare, Institutions: Social Problems, services, and Current Issues defines social work as follows; Social work is the professional activity of helping individuals, groups, or communities, to Enhance or restore reviews their capacity for social functioning and to create conditions favorable to reviews their societal goals. According to Zastrow, social work is a professional activity to helps individuals, groups, and communities in order to enhance 
or improve their skills in social function and create the conditions that allow to achieve community goals. The definition shows that social work is a profession that involved in relief activities. Relief is addressed to individuals, groups and communities, so that they can improve their social function and can achieve the goal of his/her life (Heru Dwi Sukoco, 1991).

International Federation of Social Workers (IFSW) also released the definition of social work profession as follows:

The social work profession promotes social change, problem solving in human relationships and the empowerment and liberation of people to Enhance well-being. Utilizing theories of human behavior and social systems, social work intervenes at the points where people Interact with Reviews their environments. Principles of human rights and social justiceare fundamental to social work. (Adi Fahrudin, 2012).

According to IFSW, the social work profession increasing social change, problem solving in human relationships and empowerment and liberation of people to enhance well-being. By using the theories of human behavior and social systems, social work intervenes at the points where people interact with their environment. The principles of human rights and social justice are fundamental for social work.

The third definition, explaining that social work is a process of professional assistance to help individuals, groups, or communities to build their ability to interact in environment so can solve social problems, with the aim to carry out its social function. The description illustrates that the profession of social work is the profession's help humans with various methods and skills that have professionalism in seeking the welfare of individuals, groups and communities.

Theoretically, social work and social welfare is clearly different. In Indonesia, social welfare try to be developed as an academic discipline, proven by there is social welfare science in various national university and private university, but the debate always arises how to see social welfare as a discipline if the terms of the philosophy of science. This debate, began when social welfare without trying to be a scientific discipline can explain for example what material from object of science, basic theory and the science community in academic association in the international world. Different with the social work, who received as applied science. Furthermore Adi explained that when viewed from the paradigm of science; epistemology, ontology, and aksiology the social work qualified to be regarded as an applied social science (Adi, 2012).

\section{Social Work As A Profession}

During its development, social work was a new profession in Indonesia, it still fighting to be able to exist and be known by the public and by other professions such as in the developing countries of Europe and America. A job can be said to be a professional profession if studied and have certain conditions that can be regarded as a profession. According to the Oxford Advanced Learner's Dictionary (Hornby, in Adi 2012, p 63), Profession is a paid job, especially those requiring further education and training. From these definitions it known that a profession is a work activity that has its price or paid, then the other terms are to have such work must be from people who have the capabilities that have been developed from the education and training linearly with that job. On the other sources said that the profession is a job that requires further training in a field of cultural knowledge or science, and usually involving mental work than handwork. (Adi, 2012).

Social work now carried out in some universities or colleges in the world and in Indonesia in particularly as stand-alone courses. In some colleges also social work education is part of the faculty or course of social welfare. This is the main foundation of social work can be regarded as a profession, because of the higher education, the prospective social workers acquire the knowledge, skills, values, dissemination to the public, alumni and students can form a profession organization, professional standards and the establishment of a variety of things others who can support the creation of a professional social worker. 
Moreover, Ernest Greenwood on Johnson and Yanca (2001) has stated that all professions seem to posses (1) systematic theory, (2) authority, (3) community sanction, (4) ethical codes, and (5) a culture. These are the attributes most often referred to in social work literature when discussing social work as profession, L. Leighninger (2001) also agree with this statement because that process model focuses on movement toward professional status, particularly the development of professional organizations and professional education.

\section{Student in Social Work}

By the end of the 19th century, social work gradually evolved from the apprenticeship method with the launching of the first social work training in 1898. This was a summer school established at the New York City Charity Organization Society. Six years later, in 1904, the Society established the New York School of Philanthropy, which offered eight months training in social work. Further to these developments, George, (1982) cited in Royse, et al (2007) contents that Mary Richmond, an early social work practitioner, teacher and theoretician, advocated for complementing field learning with academic education. Royse, et al (2007) also quote Austin (1986) who observes that early in social work education, students spent about half of their academic time in field settings (Dhemba, 2012).

Formal social work education in Indonesia starts in secondary level. Its established with decree Ministry of Education : No SK : 24/C, Date : 04-09-1946, the Ministry of Education and established the Sekolah Pembimbing Kemasyarakatan (SPK) in Solo, Central Java. Formal social work education in college level in Indonesia started in 1957 when the Ministry of Social Affairs (MSA) launched its Kursus Dinas Sosial A (KDSA), a one year short-term course program and the Kursus Dinas Sosial Menengah dan Atas (KSDA) course extends to Kursus Kejuruan Sosial Tingkat Menengah dan Tinggi (KKSMT), a two year training program. This course considered as early formal education and training center to improve the quality of human resource in the ministry of social (Adi, et all, 2014).

There was no objection data, showing how much a graduate student of social work or social welfare produced every year in Indonesia. But more than 30 major and department of social worker exist in Indonesian college education and some high school provide vocational sector for social work this assets facing a challenge to produce a social worker to intervention to helps people connect with needed resources and to negotiate problematic situations which might also involve changes to existing structures where these present blocks to human growth and development. assist community solving the social problem (IPSPI, 2013). Whereas, according to Indonesian Ministry of Social, Indonesia need at least 15.000 social worker to address a social problem in this country (Al Jufrie, 2012).

Student of social worker, just created by social welfare education system, where theory and practice are equally important. Leading social work scholars, among them, Kaseke (1986), Mupedziswa, (1997) and Osie-Hwedie (1996) cited on Dhemba also unequivocally assert the importance of both field instruction (fieldwork) and classroom instruction. therefore self-evident, even from the history of social work in Europe and North America where it originated, that social work education and training has always embraced the view that fieldwork and classroom instruction are essential elements of social work education (Dhemba, 2012).

\section{Method}

\section{Research Design}

The method used in this study is a qualitative approach, the procedure that produces descriptive data in the form of words of a written or oral from people and observed behavior (Bogdan and Taylor in Lexy J. Moleong, 2002). Therefore, from the research produce spoken words, ideas, opinions, information, comments and impressions other things obtained from informants comprised of students of secondary data available. Then this research carried out by a case study. This case study used by researchers, in order to researcher can observe the phenomenon more deeply and more specific and focused. Yin (2002) stated that case study is empirical information collection, which examines the social phenomena 
in the context of real life. If the boundaries between phenomenon and context can not be seen real, the various types of sources and evidence to be used in support of this study.

\section{Research Setting}

Indonesia was a country of the researcher and selected for the study be conducted in two cities, the Bandung city in West Java Province and the Makassar city in South Sulawesi. The college in Bandung and Makassar which would be a location and information collect at universities that have departments/major of social workers and social welfare.

\section{Informant Selection and Data Sources}

This study design as described previously done by qualitative, for the informant selection done by purposive and find them by snowball method. Informant withdrawal determined in accordance with the properties or characteristics that have been determined in accordance with the purposes of this study. The category required informants in this study consisted of; (1) students in higher education with educational focus concentration on Social Work and Social Welfare; (2) has been following the whole process of education and practicum or temporarily enroll in Semester 7 or 8; (3) Students stratum 1 or diploma 4 , by reason of new students at this stage to obtain and recognize education as a fundamental social workers so that interesting when doing research on reflection readiness to become a social worker (4) Students who were active and perform also student did not so active in campus activities and not jointed any activity. The secondary data on this study was data or supporting information obtained from the documents relating to the informant educational process, the college or university, professors or lecturers, and other information sources. This secondary data obtained from the qualitative data collection techniques. Secondary data collection was to complement and support the questions on this study.

\section{Data Collection Technique}

Data collection techniques used in this study to obtain comprehensive information about the social work reflection by students. As for some of the data collection techniques used including in-depth interviews (depth interview), observation and participation of the educational life of informants (observation participation) and through several studies documentation (literature review). Data collection techniques to gather important information about the study. Here presented an explanation of these techniques. The data collected from six informant that gave all information about reflection about social work.

\section{Data Analysis}

In processing and analyzing qualitative data, researchers have reference to the analysis of qualitative data according. The process of data analysis have done by content analysis approach, began by reviewing all available data finding from various sources like interviews, field notes, observation records, personal documents, official documents, images, photographs, and other sources. After researcher has studying and reviewing the data and condensed it to data transcript and made it systematically comparable, next step researchers did content analysis by data reduction into a collection of transcript that consists of statements that have a relation with the purpose of this study. The data transcript made into coding scheme, the coding scheme include all of statement and noted that can answer all of the research question. Then the researcher had work on processing unit, categorization and then interpretation of data where the data previously carried out the validity of the data (Moleong, 2000).

\section{Data Interpretation}

The interpretation of the data is compiling data obtained by linking the categories within the framework of the system obtained from the data. In this case the researcher interpreted and give 
meaning to the relationship between categories so the relation between categories was becoming increasingly apparent. This process was performed after endorsement or validation data.

\section{Result}

During the research, six students were asked about how they made a decision to continue their study in social work or social welfare and did they recognize a social work profession before decided to study in social work or social welfare. The summary of the research results revealed some reason how they made a decision to continue in social work or social welfare; some student obey to their parents or family wants, so they decided unwillingly to made their own choice, another reason revealed because of the campus has a future chance to work for government (ASN) after graduate, although any indeterminancy at latterly, but that promote made an enthusiastic reason for them to apply, the last reason they were in a pinch, there was some situation and condition to made them perforced to continue study in social work or social welfare without impression.

In the following way, six informant explain the point of their reason why they decided to continue to study in social work;

\section{Informant 1}

at the first I study in the major of social workers because, trying to apply in psychology but has not passed, finally because parents have a friend connection in $* * * * * * * * * * * * * *$ so, I follow my parents bro

He decided to study in Social Welfare / Social Work because there was no choice after had failing in psychology and decided to follow the advice of his parents who had definitely passed since it has a relationship with somebody who work in social welfare major, so he followed his parents without knowing what a social welfare was.

\section{Informant 2}

When I studied in social welfare, actually not a purpose, because my purpose in political science and Law of Syariah. But in my third option was chosen by seniors. The third option also I did not know why social welfare was given in my application.

Yeah it turns out I did not deserved in there, my soul in the social, political, law. I registered in law and in socio-political but not accepted, Jus in Social welfare. I even once said to my senior, I regret to sign in sosial welfare major.

He became a student of social welfare because of necessity, when he did not pass at the first choice (science of law), then the second choice (political science), he then passed on the third option (social welfare) chosen by seniors, because it was no other choice to found other majors. By the reason that $\mathrm{He}$ has no soul in social welfare, than he even asked to seniors that he regreted study in social welfare major.

\section{Informan 3}

At that time in Bandung, I want to study in ********** but the tuition is very expensive I think my parent could not pay for that, and in Semarang, all universities has been closed for a new apllication.

Then my parent, I recommended to study in *******, fortunately my father have any family working there .. so, I don't care, I just want to study 
anywhere where my father agree with it, and also that campus nice and widely known.

He took a chance to study in social welfare because he initially wanted to go elsewhere, but because some universities have been closed for registration and the university he wanted to apply. According to informant, the college tuition fee was very expensive, due to financial limitations which is owned by his family, he want to choose the universities or major that could reach financially, and his father had a good relationship with the staff in the department of social welfare at the university. The campus tuition fee adjust with parent income, so he can be enrolled without the high cost, in addition name of the campus was famous and recognize by public be another reason why he decided to study in his campus.

\section{Informant 4}

I have study in gynecology, but it just 2 month and my brother call to study same with him

She decided to study on social welfare, due to follow the will of his older brother who also study at the same university and same major, the current reason actually, because her brother want to take care of her as a responsibility of older brother, because they live together without parents.

\section{Informant 5}

I was know it was a government school, I thought it was like a STAN, IPDN, who once passed directly right employed in the government. Before here I also lists in other places. Pass from high school directly I try to list in at medical UNS, I was pass in PMDK but did not accept, I accepted be a teacher of mathematics. but here also try coincidence also qualify. I decided .......... mas .. because it was government campus.

When deciding majored in Social Welfare, she did not compare between major to major but by major to campus, she was faced with the choice to continue to math education teacher, or apply to the campus which is a college under government, think that she will have a great opportunity to become civil servants or Aparatur Sipil Negara (ASN), she made a decision to ensuring his future with a great opportunity to work in government.

\section{Informant 6}

Then I was confused after graduation where I wan to go, then I see on the internet, ohh there was $* * * * * * *$ campus then it was also official ministry campus..

He has confused when he wanted to continue his study in graduate level, he obtained information on the Internet and found that college under government same with the official campus IPDN and STAN who have better prospects because it could be a civil servant (ASN). It seemed like he had no motivation to become a social worker, but still wanted to study at that college by motif want to become a civil servants.

Another question they answered about, did they recognized about profession of social work. By all of the answers from informant, when settled on social welfare or social work, all of them did not know about social worker profession, and there was no motivation to continue studying to be a social worker. The best effort when some informant looking for information about social worker/social welfare before went to university, at least they knew that this is all good and positive, so they felt no doubt to study in social work, just want to study in next level at campus. They entered into the system that they did not know before and did not count much earlier. 


\section{Conclusion}

By all the social problem that happened in community as a reason why social worker needed. To produce a competent social worker, institutional training to educate the people to be a social worker necessary. To answer that needs, social work education system provide the college as a graduate level give an opportunity to people who want to apply social work/social welfare major. The phenomenon about the reason of the student apply about social work or social welfare major revealed on this study, a kind motive explain why students made a decision to choose to study in social work or social welfare. By case study, researcher success got a motives of six informant student of social welfare/social work major that include on three point; (1) student decided to continue study in social work because they obey their parents and family, they did not choose by themselves but the parents or family have a full contribution to made a choices, (2) The famous campus and prospects of the campus in the future for alumni to work for government (ASN) convinced student about their choice, (3) they were in a situation, where they have to made a choice in order to make the best use of opportunity to study in the college level.

Another question have to answered about, how they recognized about profession of social work. According to all informant, the best effort they did when informant looking for information about social worker/social welfare before went to university, at least they knew that this is all good and positive matter, they never saw the real social worker. All of them did not know about social worker profession, and there was no motivation to continue studying to be a social worker, so they felt no doubt to study in social work, just want to study in next level at campus.

\section{Recommendation}

This study emphasizes on give attention to social work and social welfare education system, where the candidate of social work student have to know and recognize about profession of social work and when they graduate they know what exactly the decide next. Another recommendation, the institution in education and practice field optimize social work existence in public by effective work, using all of media (conference, seminar, mainstream media, social media, report etc.) to make a people, high school student, layman or community recognize the profession of social worker. The last, writer invite and challenge all social worker, practitioner, educator to encourage government to legitimating social work act in Indonesia. .

\section{References}

Adi Fahrudin. (2012). Pengantar Kesejahteraan Sosial. Refika Aditama: Bandung

Adi Fahrudin, Husmiyati Yusuf, Binahati Rusyidi. (2014). Indigenization of Social Work Education and Practice In Indonesia. Internationalization Indigenization of Social Work Education in Asia. 61-84.

Dwi Heru Sukoco. (1991). Profesi Pekerjaan Sosial Dan Proses Pertolongannya. Koperasi Mahasiswa Sekolah Tinggi Kesejahteraan Sosial: Bandung

Dubois B., \& Miley K.K. (1999). Social WorkAn Empowering Profession Third Edition. Allyn and Bacon. USA

Edi Suharto. (2007). Seminar Paradigma Kesejahteraan Sosial, Jurusan Pengembangan Masyarakat Islam,Universitas Islam Negeri Sunan Kalijaga, Yogyakarta 5-6 September 2007.

Fahrudin, A. (2013). Social Welfare and Social Work in Indonesia. In FURUTO S. (Ed.), Social Welfare in East Asia and the Pacific (pp. 136-157). Columbia University Press. Retrieved from http://www.jstor.org/stable/10.7312/furu15714.11

Fink A.E., Wilson E.E., Conover M.B. (1963). The Field Of Social Work Fourth Edition. Holt, Rinehart And Winston, INC: USA

History of American Association of Social Workers (AASW) (1918-1955). Retrieved From http://www.socialwelfarehistory.com/organizations/american-association-of-social workers/

Ikatan Pendidikan Pekerjaan Sosial (IPSPI) 2013 (http://www.kemsos.go.id ) 
Jotham Dhemba. (2012). Fieldwork in Social Work Education and Training: Issues and Challenges in the Case of Eastern and Southern Africa. Digital Peer Pulishing Vol 10, No 1 (2012) : National University of Lesotho

Johnson L. C., Yanca S. J. (2001). Social Work Practice A General Approach. Seventh Edition. Allyn and Bacon: USA

Kirst-Ashman, Karen K. (2007). Introduction to social work and social welfare: Critical thinking Perspectives, Second Edition. Thomson Brooks/Cole: USA

Lauffer Arman. (1987). Working In Social Work: Growing And Thriving In Human Service Practice. SAGE Publication: California

Morales A.T., Sheafor B. W. (1998). Social Work A Profession of Many Faces Eight Edition. Allyn and Bacon: USA

Newman W. L. (2011). Social Research Methods Qualitative and Quantitative Approaches Seventh Edition. Pearson: Boston

Segal, E.A., Gerdes K.E., Steiners S. (2007). An Introduction to the Profession of Social Work Becoming a Change Agent Second Edition. Thompson Brooks/cole: Canada

Salim Segaf Al Jufri. (2012). Orasi Ilmiah Kementrian Sosial Republik Indonesia, Mengembangkan Pekerjaan Sosial Dalam Konteks Indonesia. Bandung. Retrieved From Buku Panduan Wisuda STKS Bandung ke-46.

Thompson Neil. (2000). Understanding Social Work Preparing for Practice. Palgrave: Wales 